\title{
UJI BERBAGAI ALAT DETEKSI BIRAHI TERHADAP ANGKA KEBUNTINGAN PADA SAPI PERAH DI KOPERASI TUNAS SETIA BARU KABUPATEN PASURUAN
}

\section{TEST VARIOUS ESTRUS DETECTION DEVICE AGAINST PREGNANCY RATES ON DAIRY COWS IN COOPERATIVE TUNAS SETIA BARU KABUPATEN PASURUAN}

\author{
Silvia Rani Andriyanti ${ }^{1)}$, Mas'ud Hariadi' ${ }^{2}$, Roesno Darsono ${ }^{3)}$, Pudji Srianto ${ }^{4}$, \\ Wurlina $^{5)}$, Tjuk Imam Restiadi') \\ ${ }^{1)}$ Student, ${ }^{2,4,5,6)}$ Veterinary Reproduction Department, ${ }^{3)}$ Pathology veterinary Department \\ Veterinary Reproduction Department ${ }^{4)}$ \\ Faculty Veterinary Medicine, Airlangga University \\ ranisilvia26@gmail.com
}

\begin{abstract}
This research aims to determine the use of various estrus detection devices before artificial insemination as measured by pregnancy rate. The researcher used a sample of 60 cows were used in this research which is divided into four groups as a control and treatment groups (Thermopin®, Hauptner and Draminski groups), and each cow was detected for the sign of estrus by three devices that were Thermopin ${ }^{\circledR}$, Hauptner and Draminski prion when doing an artificial insemination. The cows were observed to 45 days after artificial insemination for observing pregnancy. This research method is the exploration scope to prove the effect of various estrus detection tool against pregnancy rates. The result of ANOVA test, there is the effect of using a various estrus detection devices against pregnancy rates. Samples tested by Draminski with average $(1.53 \pm 0.51)$ resulted in a $53,3 \%$ pregnancy rate, the samples were tested with Hauptner with average $(1.67 \pm 0,48)$ resulted in pregnancy rate $66,7 \%$. Without treatment or control, sample with an average of $(1.67 \pm 0,48)$ resulted in a $73,3 \%$ pregnancy rate. While samples were tested with Thermopin ${ }^{\circledR}$ with average $(2.00 \pm 0,00)$ resulted in a $100 \%$ pregnancy rate. In conclusion, Thermopin ${ }^{\circledR}$ the best detection tool than other estrus detection devices.
\end{abstract}

Key Words : estrus detection, artificial insemination, dairy cow, pregnancy rate

\section{Pendahuluan}

Proyeksi produksi susu segar dan pasar susu nasional dari tahun 2010 sampai 2015 belum mampu dipenuhi oleh produksi dalam negeri. Selain karena jumlah populasi sapi perah nasional yang masih terlalu sedikit, modal juga menjadi kendala bagi peternak untuk mengembangkan usahanya. Berdasarkan data Dewan Persusuan Nasional tahun 2012 menunjukkan bahwa proyeksi produksi dan kebutuhan susu segar dalam negeri pada tahun 2010 sampai 2015 memberitahukan bahwa permintaan susu segar pada tahun 2010 hingga 2015 diperkirakan mengalami peningkatan rata-rata 6,3 persen per tahun. Namun demikian, penawaran susu segar relatif tetap. Kebutuhan susu nasional pada tahun 2010 yang mencapai 3,1 juta ton hanya dapat dipenuhi sebesar 690.000 ton, sedangkan pada tahun
2011 kebutuhan susu nasional 3,2 juta ton hanya di suplai produksi susu dalam negeri sebesar 800.000 ton susu, dan sisanya masih impor. Bahkan pada tahun 2011 sampai 2015 diperkirakan produksi susu relatif tetap pada jumlah 800.000 ton, sedangkan kebutuhan susu nasional terus mengalami peningkatan antara 200.000 ton sampai 300.000 ton tiap tahunnya (Gofur, 2013).

Rendahnya tingkat produktivitas sapi perah disebabkan oleh banyak faktor diantaranya kurangnya pengetahuan peternak mengenai manajemen pakan ternak, keterampilan peternak untuk menandai kejadian birahi sapi dan waktu pelaporannya, ketepatan waktu IB (Hardijanto dkk., 2010). Masalah reproduksi sapi perah yang sering terjadi adalah rendahnya angka kelahiran karena rendahnya tingkat kesuburan terkait kasus gangguan reproduksi. Sebagai salah 
satu upaya yang dapat dilakukan untuk menanggulangi permasalahan yang menghambat peningkatan populasi ternak yaitu dengan dilakukannya teknik Inseminasi $\mathrm{Bu}-$ atan (IB) yang bertujuan untuk meningkatkan efisiensi reproduksi (Hafez, 2000).

Seiring berkembangnya teknologi muncul alat-alat deteksi birahi yang dapat memudahkan inseminator untuk menentukan waktu optimal saat dilakukan IB. Kinerja alat otomatis deteksi estrus pada umumnya lebih tinggi dari $75 \%$, tergantung pengaturan untuk ambang batas dan periode yang telah disesusaikan yang digunakan untuk menentukan estrus tersebut (Chanvallon et al., 2014).

\section{Tempat dan Waktu Penelitian}

Penelitian ini dilaksanakan di Koperasi Unit Desa Tunas Setia Baru Kabupaten Pasuruan. Penelitian dilaksanakan pada bulan September-Desember 2016.

\section{Bahan dan Alat Penelitian}

Penelitian ini menggunakan 60 ekor sapi Peranakan Friesian Holstein betina dewasa umur berkisar $\pm 2-6$ tahun dengan berat badan 500-600 kg. Alat untuk penelitian ini adalah 3 alat deteksi birahi yaitu Thermopin $®$, Hauptner dan Draminski yang digunakan untuk mendeteksi waktu yang tepat untuk dilakukan Inseminasi Buatan pada sapi perah. Bahan untuk penelitian ini adalah 60 straw semen beku sapi perah digunakan untuk pelaksanaan Inseminasi $\mathrm{Bu}-$ atan di dataran tinggi (produksi BBIB Singosari), alkohol dan kapas digunakan untuk menjaga alat deteksi birahi agar tetap bersih setelah digunakan.

\section{Metode Penelitian}

Penelitian ini merupakan penelitian eksploratif lapangan. Sampel sapi perah birahi didapatkan dengan cara mengikuti inseminator saat akan melakukan Inseminasi Buatan (IB). Sampel sapi perah birahi didapatkan dari laporan peternak berdasarkan tanda-tanda birahi pada ternak. Sampel sapi perah birahi yang didapat tidak dilakukan sinkronisasi birahi sebelumnya. Sebelum dilaksanakan IB pada ternak dilakukan deteksi birahi terlebih dahulu terhadap sapi betina birahi menggunakan alat-alat deteksi birahi setelah itu dilaksanakan IB oleh inseminator.

Pengumpulan sampel dilakukan dengan cara mendeteksi sapi perah betina birahi dengan menggunakan alat deteksi birahi yang telah disiapkan apabila hasil pengukuran sudah sesuai dengan parameter yang telah ditetapkan pada setiap alat untuk menentukan waktu yang tepat saat di IB maka sampel tersebut dikumpulkan hingga berjumlah 15 ekor untuk setiap perlakuan.

Pemeriksaan kebuntingan dilakukan pada hari ke-45 setelah dilaksanakan inseminasi buatan, kemudian dilakukan pencatatan (No/Nama pemilik/Tanggal IB/Hasil pengukuran dengan alat deteksi birahi/Tanggal PKB/Hasil).

\section{Hasil Dan Pembahasan}

Telah dilakukan uji berbagai alat deteksi birahi pada sapi perah sebelum dilakukan inseminasi buatan terhadap angka kebuntingan pada sapi perah. Penelitian ini menggunakan sampel 60 ekor sapi perah yang dibagi menjadi 4 kelompok perlakuan dan masing-masing perlakuan terdiri dari 15 ekor sapi perah. Kelompok tanpa perlakuan (kontrol) terdiri dari 15 ekor sapi perah. 40 ekor sapi perah yang dibagi menjadi 3 kelompok perlakuan dilakukan pengukuran dengan menggunakan alat deteksi birahi Thermopin $®$, Hauptner, dan Draminski sebelum dilakukan inseminasi buatan. Hasil dari penelitian ini dapat dilihat pada tabel 1 .

Tabel 1. Pengukuran deteksi birahi sebelum dilakukan inseminasi buatan (rerata \pm SD) dan persentase angka kebuntingan (\%) pada sapi perah

\begin{tabular}{cccc}
\hline Perlakuan & n (ekor) & $(\mathbf{X} \pm$ SD) & Angka kebuntingan (\%) \\
\hline Kontrol & 15 & $\left(1.67^{\mathrm{a}} \pm 0,48\right)$ & $73,3 \%$ \\
Draminski & 15 & $\left(1.53^{\mathrm{a}} \pm 0.51\right)$ & $53,3 \%$ \\
Hauptner & 15 & $\left(1.67^{\mathrm{a}} \pm 0,48\right)$ & $66,7 \%$ \\
Thermopin ${ }^{\circ}$ & 15 & $\left(2.00^{\mathrm{b}} \pm 0,00\right)$ & $100 \%$ \\
\hline
\end{tabular}

Keterangan : Superskrip yang berbeda pada kolom yang sama menunjukkan perbedaan yang nyata $(\mathrm{p}<0,05)$. 
Hasil uji Duncan tersebut menunjukkan bahwa sapi perah tanpa diberi perlakuan sebelum IB (kontrol) tidak berbeda nyata dengan sapi perah yang diukur dengan menggunakan alat deteksi estrus Draminski dan Hauptner namun berbeda nyata dengan sapi perah yang diukur dengan menggunakan Thermopin®.

Pengukuran Berbagai Alat Deteksi Birahi (Draminski, Hauptner dan Thermopin $\left.{ }^{\circledR}\right)$ Sebelum Dilakukan IB Terhadap Angka Kebuntingan

Pengukuran deteksi birahi dengan menggunakan Draminski terdapat 7 ekor sapi perah tidak bunting dengan rerata alat deteksi birahi berbasis perubahan hambatan dari lendir serviks $(1.53 \pm 0.51)$ sehingga menghasilkan angka kebuntingan 53,3\%. Sedangkan sapi perah yang diukur dengan menggunakan Hauptner terdapat 5 ekor sapi perah yang tidak bunting dengan rerata alat deteksi birahi berbasis perubahan hambatan dari lendir serviks $(1.67 \pm 0,48)$ menghasilkan persentase angka kebuntingan 66,7 $\%$. Kelompok tanpa perlakuan (kontrol) terdiri dari 15 ekor sapi perah memiliki rerata $(1.67 \pm 0,48)$ terdapat 4 ekor sapi yang tidak bunting menghasilkan persentase angka kebuntingan 73,3\%. Sapi perah yang diukur menggunakan Thermopin ${ }^{\circledR}$ dengan rerata alat deteksi birahi berbasis suhu $(2.00 \pm 0,00)$ menghasilkan persentase angka kebuntingan $100 \%$.

Temperatur vagina menunjukkan peningkatan dari temperatur normal dikarenakan adanya pengaruh dari hormon estrogen yang aktif saat birahi meningkatkan suplai darah pada alat kelamin dan menimbulkan vulva lebih panas, merah, dan bengkak. Temperatur vagina yang baik saat Inseminasi Buatan di dataran tinggi dan dataran rendah adalah kurang dari $39,85^{\circ} \mathrm{C}$ dengan angka kebuntingan 68,8\%. Temperatur vagina saat Inseminasi Buatan sangat mempengaruhi angka kebuntingan sapi perah di dataran tinggi dan dataran rendah (Sofia, 2016).

Faktor penentu keberhasilan IB (yakni kualitas semen beku yang digunakan, pengetahuan dan kepedulian peternak dalam melakukan deteksi birahi, (body condition score) sapi, kesehatan ternak terutama yang terkait dengan alat-alat reproduksi, serta keterampilan dan sikap inseminator dan waktu IB yang tepat (BIB, 2011; Diwyanto, 2012: Caraviello et al., 2006).

Faktor-faktor yang menyebabkan rendahnya angka kebuntingan diantaranya adalah pakan yang diberikan kepada sapi perah. Nutrisi yang terkandung di dalam ransum harus dalam keadaan seimbang dan sesuai dengan kebutuhan. Apabila ternak mengalami kekurangan asupan makanan akan berpengaruh terhadap penampilan gejala birahi yang kurang jelas karena proses sintesa dan regulasi hormon-hormon reproduksi terganggu. Kondisi peternakan yang masih menggunakan sistem pemeliharaan tradisional dan di daerah yang kurang subur mengakibatkan ternak mengalami kekurangan nutrisi yang sangat diperlukan oleh proses fisiologi reproduksi dalam tubuh ternak tersebut (Abidin dkk., 2012). Pemberian pakan (nutrisi) yang berkualitas rendah dapat berpengaruh langsung terhadap efisiensi reproduksi (Salem dkk., 2006).

Penyebab kawin berulang (repeat breeder) pada dasarnya disebabkan oleh 2 faktor utama yaitu kegagalan pembuahan (fertilisasi) dan akibat kematian embrio dini. Kematian embrio dini sering tidak memperlihatkan kelainan yang jelas pada induk dan diikuti dengan siklus birahi yang diperpanjang menjadi 27 sampai 30 hari. Faktor-faktor yang mendorong terjadinya kematian embrio dini yaitu genetik, infeksi, lingkungan, ketidakseimbangan hormon, pakan, umur induk, kesuburan air mani, jumlah embrio atau fetus dalam uterus (Hariadi, 2011).

Umumnya yang terjadi di lapangan adalah peternak kurang terampil dalam menandai kejadian birahi pada ternaknya dan peternak juga belum mengetahui waktu yang tepat saat CR tinggi sebelum dilakukan Inseminasi Buatan. Pada umumnya keakuratan pengamatan visual peternak dalam mendeteksi birahi pada ternaknya memiliki tingkat efisiensi 50-70\%. Dengan semakin berkembangnya teknologi elektronik telah dikembangkan alat deteksi birahi dalam upaya untuk meningkatkan efisiensi deteksi birahi (Roriea et al., 2002). Deteksi birahi otomatis memiliki persentase $75 \%$ dalam ketepatan menentukan estrus pada ternak tergantung pengaturan untuk ambang batas dan periode yang telah disesusaikan 
yang digunakan untuk menentukan estrus tersebut (Chanvallon et al., 2014).

\section{Kesimpulan}

Berdasarkan hasil dari penelitian ini, maka disimpulkan bahwa alat deteksi birahi terbaik yang dapat meningkatkan efisiensi deteksi birahi pada sapi perah di Koperasi Tunas Setia Baru Kabupaten Pasuruan adalah Thermopin $®$. Sampel sapi perah birahi sebanyak 15 ekor yang diukur menggunakan Thermopin $\AA$ dengan rerata alat deteksi birahi berbasis suhu $(2,00 \pm 0,00)$ menghasilkan persentase angka kebuntingan $100 \%$.

\section{Daftar Pustaka}

Abidin, Z., Y.S. Ondho dan B. Sutiyono. 2012. Penampilan Berahi Sapi Jawa Berdasarkan Poel 1, Poel 2, dan Poel 3. Fakultas Peternakan dan Pertanian Universitas Diponegoro.

Balai Inseminasi Buatan (BIB). 2011. Buku Pintar Inseminasi Buatan. Balai Inseminasi Buatan, Lembang.Direktorat Jenderal Peternakan dan Kesehatan Hewan. Kementrian Pertanian.

Caraviello, D. Z., K. A. Weigel, P. M. Fricke, M. C. Wiltbank, M. J. Florent, N.B. Cook, K.V. Nordlund, N.R. Zwald and C.L Rawson. 2006. Survey of Management Practies on Reproductive Performance of Dairy Cattle on Large us Commersial Farms. Departement of Dairy Science, University of Wisconsin, Madison 53706. School of Veterinary Medicine, Univesity of Wisconsin, Madinson 537. Jurnal of Dairy Science. 89(12): $4723-4735$.

Chanvallon, A. S.C. Castel, J. Gatien, J.M. Lamy, D. Ribaud, C. Allain, P. Clement, P. Salvetti. 2014. Comparison of Three Device for The Automated Detection of Estrus in Dairy cows. J. Dairy Sci. 82: 734-741
Diwiyanto, K. 2012. Optimalisasi Teknologi Inseminasi Buatan Untuk Mendukung Usaha Agribisnis Sapi Perah dan Sapi Potong. Bunga Rampai. Puslitbangnak.

Gofur, A. 2013. Analisis Potensi Permintaan, Penawaran Susu Segar Dan Kelayakan Investasi Untuk Klaster Peternakan Sapi Perah Sebagai Strategi Pengembangan Kawasan Sapi Perah Di Kabupaten Jembe [Skripsi]. Fakultas Ekonomi. Universitas Jember.

Hafez, E.S.E., 2000. Reproduction in Farm Animal. $7^{\text {th }}$ ed. Lippicott Williams \& Wilkin. Philadelphia. USA. Page: 347-441.

Hariadi, M, S. Hardjopranyoto, Wurlina, H.A Hermadi, B. Utomo, Rimayanti, I.N. Triana, H. Ratnani. 2011. Buku Ajar Ilmu Kemanjiran pada Ternak. Surabaya. Airlangga University Press.

Roriea, R.W, T.R. Bilby, T.P. Lexter. 2002. Application of Electronic Estrus Detection Technologies to Reproductive Management of Cattle. Theriologieslogy 57: 137-148

Salem, M.B., Djeamali M, Koyouli C, Majdoub A. 2006. A Review Of Environmental And Management Factors Affecting The Reproductive Performance Of Holstein-Friesian Dairy Herds In Tunisia. Livestock Research for Rural Development. 18 (4).

Sofia, A. 2016. Pengaruh Temperatur Rektum dan Temperatur Vagina saat Inseminasi Buatan terhadap Angka Kebuntingan pada Sapi Perah di Dataran Tinggi dan Dataran Rendah [Skripsi]. Fakultas Kedokteran Hewan. Universitas Airlangga. 